\title{
Albert N. Greco: The Business of Scholarly Publishing: Managing in Turbulent Times
}

\section{Oxford University Press, New York, 2019, 220 pp., \$34.95, ISBN 978-0-19-062623-5}

\section{David M. Hetherington ${ }^{1}$}

Published online: 9 October 2020

(c) Springer Science+Business Media, LLC, part of Springer Nature 2020

I had the great good fortune to meet Professor Albert Greco some twenty years ago as part of a research project during my Big Five consulting days. Professor Greco and his colleagues were then engaged in the collection and publication of industry statistics on behalf of the Book Industry Study Group. To most book industry professionals, Professor Greco is probably a well-kept secret but the fact is that, at least to the best of my knowledge, there is no one who has devoted more time, attention and rigor to the study of the publishing industry. In my view, one would be hard pressed to name anyone, academic or otherwise, who has a better understanding of the economics of publishing and keeps closer tabs on the changes the industry has already gone through and continues to go through.

Professor Greco's body of work about publishing industry is nothing short of remarkable. He is the author or editor of 16 scholarly books and 10 professional books as well serving on the editorial on the editorial board of three scholarly journals. The Business of Scholarly Publishing is a superb addition to an already remarkable career as an academic and author and a "must-read" for everyone in the leadership of scholarly publishing or with aspirations to join these ranks.

Scholarly Publishing discusses both the journal and book publishing sectors in ample detail in this impeccably researched volume. This is an especially important volume because it discusses the issues and opportunities facing the scholarly publishing community in a clear, concise, and comprehensive fashion, thankfully without engaging in a polemic about the justification for open access. This book is, in many ways, a call to action that provides the reader of a comprehensive view of the landscape-past and present while simultaneously offering options for the future.

A central theme of this impressive work is that, "scholarly publishing is a business, it is not a social service". In many ways this is a book about survival and Professor

David M. Hetherington

david.hetherington@knk.com

1 knk Software, 89 Headquarters Plaza, Morristown, NJ 07960, USA 
Greco does not pull any punches discussing the challenges facing the academic publishing community-regardless of whether the publishing organization is a member of the commercial or non-profit sector. Greco states that "The entire scholarly publishing sector in the United States is witnessing tremendously important tectonic changes".

Bear in mind that Professor Greco's admonition of tectonic change was made well before Covid-19 began to wreak havoc on the globe and if there were challenges to the scholarly publishing community before the virus, those challenges have surely grown exponentially over the course of the last six months.

It is these more recent environmental changes that make The Business of Scholarly Publishing: Managing in Turbulent Times an especially important book. Greco discusses the history of both the scholarly book and journal businesses in ample detail and provides the reader with especially useful examples of the business models for both. Perhaps most important, Professor Greco does not shy away from discussing the challenges facing these communities, whether commercial or non-profit, and the actions they might take to manage in a landscape that is migrating from $100 \%$ print, to a hybrid that offers print and digital, and now shows significant signs of migrating to $100 \%$ digital delivery model under growing pressure to move to $100 \%$ open access, a migration that has surely been accelerated by the Covid-19 pandemic.

As the Fall 2020 semester approaches and few signs that the Covid-19 pandemic is abating in the United States, the scholarly publishing community is facing unprecedented challenges as higher education expands the use of on-line delivery, open education resources garner more attention, and academic libraries conduct a top-to-bottom examination of their mission including how they manage their collections, the services they offer, and facilities they have traditionally made available to students and professors alike. Unquestionably, the pressure on academic library budgets will only be exacerbated as a necessary countermeasure to the economic damage done by Covid-19.

It is these latest and unprecedented challenges that makes The Business of Scholarly Publishing such an important addition to the literature. Professor Greco provides an unflinching look at the history and the environmental complexities that publishers are facing but also provides reason for optimism (albeit tempered) and potential structural and operational solutions. This is not to suggest that there are easy fixes but if there was ever a time when a clear-eyed assessment is called for, this is that moment.

This book provides a clear-eyed assessment of the landscape and should be required reading for all scholarly publishers, whether book or journals, commercial or nonprofit, print, or digital, STM, HSS, or LTR and especially for the university press community. It is worth noting that this remarkable book was published by Oxford University Press, one of scholarly publishing great names and this unblemished look at this sector of the industry is most welcome.

Publisher's Note Springer Nature remains neutral with regard to jurisdictional claims in published maps and institutional affiliations. 